\title{
Corrigendum to "Management Challenges in a Child with Chronic Hyponatremia: Use of V2 Receptor Antagonist"
}

\author{
Sowmya Krishnan, ${ }^{1}$ Swapna Deshpande, ${ }^{2}$ Ashwini Mallappa, ${ }^{1}$ Divya Gunda, \\ Pascale Lane, ${ }^{1}$ Anu Vishwanath, ${ }^{1}$ and Rene Y. McNall-Knapp ${ }^{1}$ \\ ${ }^{1}$ Department of Pediatrics, University of Oklahoma Health Sciences Center, Oklahoma City, OK, USA \\ ${ }^{2}$ Department of Psychiatry, University of Oklahoma Health Sciences Center, Oklahoma City, OK, USA \\ ${ }^{3}$ Department of Radiology, University of Oklahoma Health Sciences Center, Oklahoma City, OK, USA \\ Correspondence should be addressed to Sowmya Krishnan; sowmya-krishnan@ouhsc.edu \\ Received 29 May 2017; Accepted 1 June 2017; Published 2 July 2017
}

Copyright (C) 2017 Sowmya Krishnan et al. This is an open access article distributed under the Creative Commons Attribution License, which permits unrestricted use, distribution, and reproduction in any medium, provided the original work is properly cited.

In the article titled "Management Challenges in a Child with Chronic Hyponatremia: Use of V2 Receptor Antagonist" [1], the name of the fourth author was reversed. The author's name should have been written as Divya Gunda. The revised authors' list is shown above.

\section{References}

[1] S. Krishnan, S. Deshpande, A. Mallappa et al., "Management challenges in a child with chronic hyponatremia: use of V2 receptor antagonist," Case Reports in Pediatrics, vol. 2017, Article ID 3757423, 4 pages, 2017. 


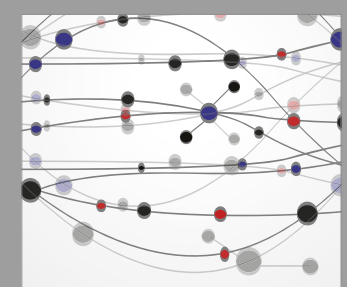

The Scientific World Journal
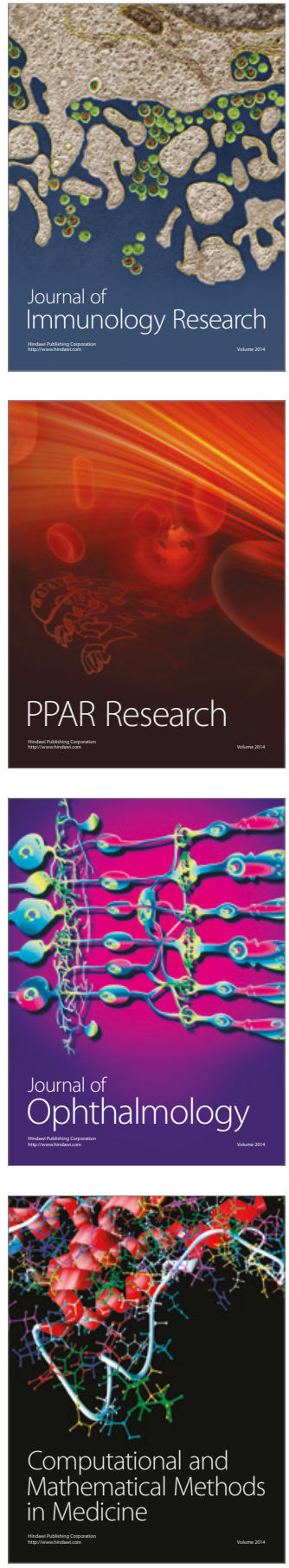

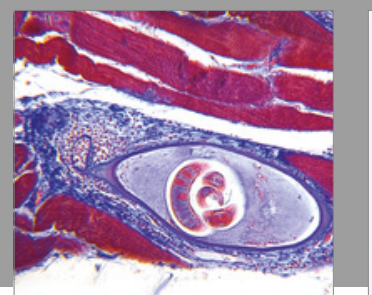

Gastroenterology Research and Practice
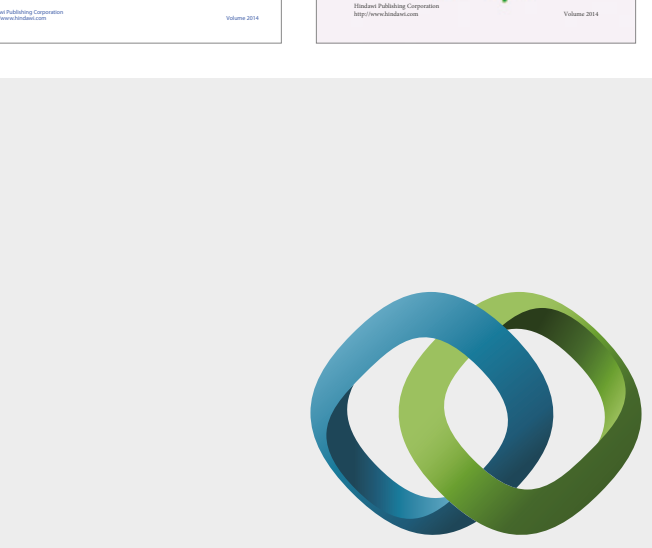

\section{Hindawi}

Submit your manuscripts at

https://www.hindawi.com
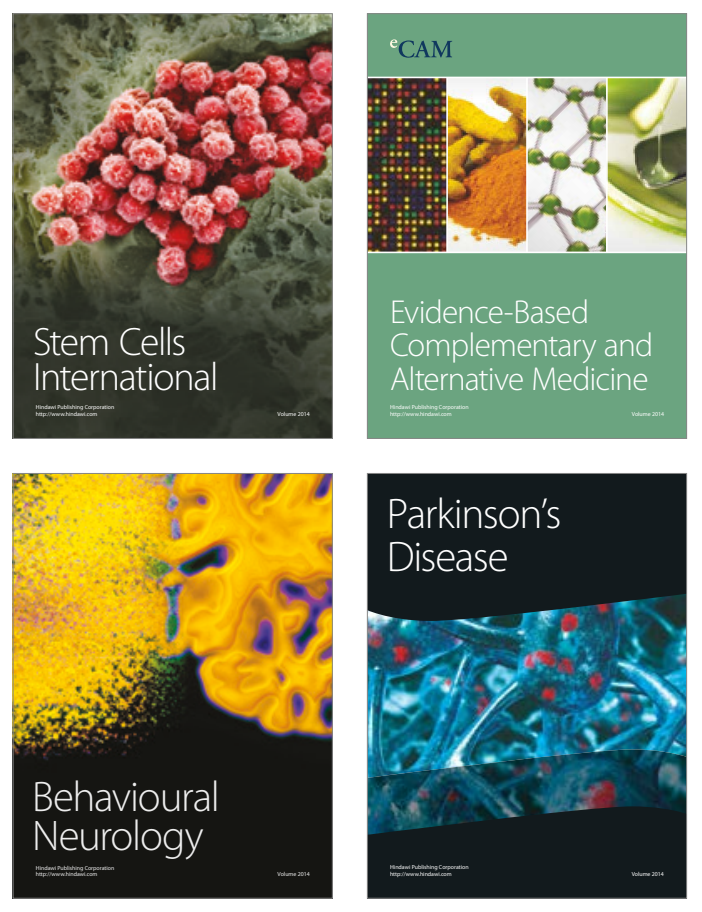
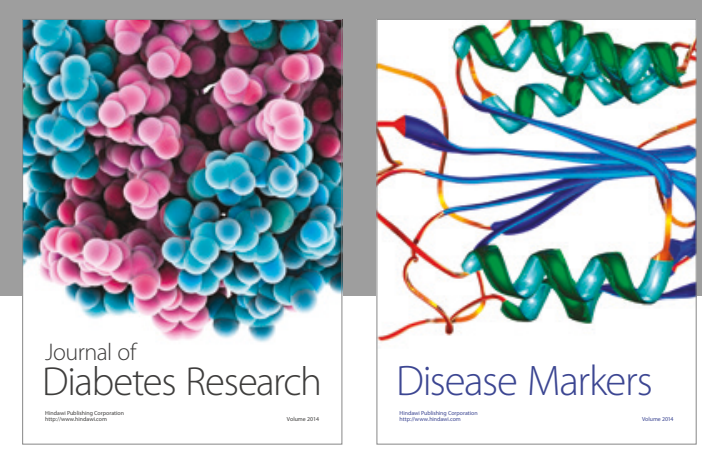

Disease Markers
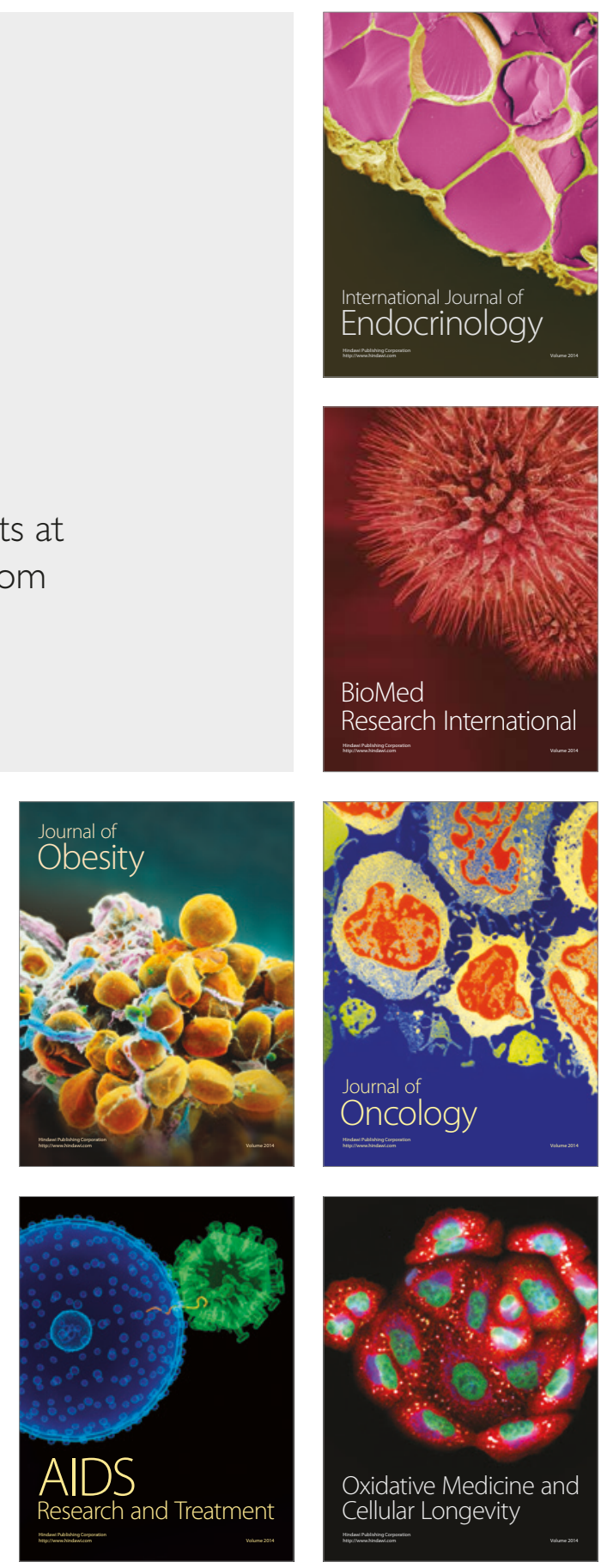